\title{
IMPROVING THE GREENHOUSES MACROCLIMATE OF HOT AND HUMID REGIONS BY MODIFIED EVAPORATIVE COOLING SYSTEM
}

\author{
Gaber D. M. Youssef ${ }^{1}$ and Nasser M. El-Ashmawy ${ }^{2}$
}

ABSTRACT

In hot and humid regions such as around the Equator, coastal areas and Mediterranean basin, crop growth in greenhouses during hot and humid summer is almost impossible because of the excess temperatures accumulated inside causing plant stress and welt. The aim of this experimental work was to investigate the effects of a developed evaporative cooling system on the greenhouse macroclimate and productivity of tomato crop. Two similar gable-even-span greenhouses were utilized at EL-Sabahia Horticultural Research Station, Alexandria (as a Costal region), to produce tomato crop during the summer seasons of 2014 and 2015. Each greenhouse was equipped with a complete evaporative cooling system. One of them was modified (MECS) by obstruct the humid ambient air by a granule silica gel sieve. Whereas it absorbs the excess moisture of ambient air prior to passing through the cooling pads. The other one used the traditional fan-pad evaporative cooling system, (FPECS).

The obtained results illustrated that, the averages air temperature after leaving the cooling pad, greenhouse air temperatures, relative humidity, efficiency and vapor pressure deficit were $\left(21.6-28.2{ }^{\circ} \mathrm{C}\right),(29.2-33.4$ $\left.{ }^{\circ} \mathrm{C}\right),(65.2-71.4 \%),(89.2-62.1 \%)$ and $(1.39-1.50 \mathrm{kPa})$ for MECS and FPECS greenhouses, respectively. The maximum greenhouse temperature decreased below the outside temperature by $2.9{ }^{\circ} \mathrm{C}$ for MECS while, it increased by $1.6^{\circ} \mathrm{C}$ over it for FPECS. The percentages increase in early yield, number of fruit per plant, fruit weight, total yield per plant and total yield per feddan were 14.07, 9.43, 8.00, 18.15 and 18.13\%, respectively for MECS greenhouse over FPECS greenhouse in 2014 season, while they were $12.41,12.98,7.90,22.06$ and 21.97\%, respectively in 2015 season.

Keyword: Evaporative cooling - greenhouse - silica gel - tomato

\footnotetext{
${ }^{1}$ Senior Researcher, Horticulture Res. Institute, A.R.C, Giza.

${ }^{2}$ Senior Researcher, Agricultural Engineering Res. Institute, A.R.C., Giza
} 


\section{INTRODUCTION}

7 Trced greenhouse crops are common means of cultivation worldwide. Surface area dedicated to such crops about 700,000 ha,

150,000 of which are located in the Mediterranean basin (Franco et al., 2014). High spring-summer temperatures in the Mediterranean basin make cooling systems necessary. Excess heat causes air temperature to become hotter over than the desired level resulting in detrimental effects on crop growth and production (Montero, 2006). Reducing temperatures is one of the main problems facing greenhouse management during daylight in hot-humid summer conditions such as in Egypt (Abdellatif et al., 2010). They mentioned also, that air temperatures in Egyptian greenhouses either covered with polyethylene or fiberglass can easily exceed $50{ }^{\circ} \mathrm{C}$ during the hot summer if they are not equipped with cooling system. Air cooling is desirable in many Mediterranean greenhouses in order to prevent plant stress and produce crops of marketable quality. Mechanical cooling can efficiently maintain greenhouse air temperature and relative humidity at acceptable levels during warm periods, but it is so costly and not friendly environmental system (Kittas et al., 2003).

The evaporative cooling theory is based on the evaporation of water in mass of dry and warm incoming air, thus allowing a decrease in the air temperature and increases the air relative humidity, (Kittas et al., 2003, Montero, 2006, Farmahini et al., 2012 and Jamaludin et al., 2014). Evaporative cooling is a cost effective and eco-friendly alternative but its efficiency is higher in dry environments where humidity is less than $30 \%$. As humidity rises the efficiency falls (Garzoli, 1989, Montero and Segal, 1993, Lychnos, 2010, Bhatia 2012, Evaptainers, 2014 and Rafique et al., 2016). The air saturation efficiency of the pad-fan system is greater than that of the fog system (Katsoulas et al., 2009). It is also cheaper (Sethi and Sharma, 2007). It consumes less water and energy (López et al., 2012). Evaporative cooling unit with perforated ducts throughout the greenhouse kept the air temperature distributed uniformly and kept the greenhouse temperature at the optimum acceptable level, (Youssef et al., 2015). Also, Youssef and Yakout, (2015) found that evaporative cooling system with local pad materials, (rice straw, loaf and 
cotton thread) when utilized with black shading net $60 \%$ permitted the cooling demands of greenhouse in spring and summer's of Egypt.

Silica gel's high surface area (around $800 \mathrm{~m}^{2} / \mathrm{g}$ ) allows it to adsorb moisture rapidly, making it useful as a desiccant (drying agent). The silica-gel has a great capacity to absorb moisture of around 35 to $40 \%$ of its dry mass, along with low regeneration temperatures, (Tahat, 2001). Liquid desiccant with solar regeneration is considered as a means of lowering the temperature in evaporatively cooled greenhouses, (Davies, 2005), therefore, numerous researchers were worked in enhancing the efficiency of the evaporative cooling systems for greenhouses in hot and humid regions using both liquid and solid desiccant materials, (Bourouni, 2008, Lychnos and Davies 2008, Lychnos, 2010, Joudi and Hasan, 2013,. Franco, et al., 2014). Mohammad et al., (2013) mentioned that in hot and humid areas, the liquid desiccant air-conditioning systems stand on evaporative cooling was introduced as an alternative to the conventional vapor compression systems due to its benefit in, eliminating the air latent load, friendly environment and conserving energy. Mishra et al., (2016) reported that the evaporative cooling system can be worked accurately in coincidence with desiccant dehumidifier. Many investigators included the author in previous paper; (EL-Bakhashwan et al., 2013) investigated the regeneration of moist silica gel and concluded that silica gel can be regenerated using solar drying system at temperatures around $60{ }^{\circ} \mathrm{C}$. So, it could be reused again and again without significant decrease in its efficiency. Desiccant has a possession of regeneration so it can be reactivated and reprocessed, (Bora et al., 2017).

Vapour Pressure Deficit, or VPD, is the difference between the amount of moisture in the air and how much moisture the air can hold when it is saturated. The ideal range for VPD in a greenhouse is from 0.45 to 1.25 $\mathrm{kPa}$. The ideally sitting is at around $0.85 \mathrm{kPa}$. The danger level is VPD > $2.0 \mathrm{kPa}$, (Autogrow, 2012). Shamshiri et al., (2016) found that the optimal vapor pressure deficit (VPD) borders at the flowering to mature fruiting stages for tomato plant were 0.596 to $1.425 \mathrm{kPa}$.

In Egypt, the late summer market of tomato crop is yielded from transplants planted into the open field during April up to June. During this period, temperature can exceed $35^{\circ} \mathrm{C}$ under field condition resulting in 
either non-uniform growth and poor fruit yield or even completely failure of tomato cropping in a great part of the cultivated area, (Pressman et al., 2002; Adil et al., 2004). With regard to the effect of temperature on growth and productivity of tomato plants, Saeed et al., (2007) found that high temperatures is the main detrimental reason to growth, reproductive development and yield of several crops. In summer high temperature during reproductive development caused significant increment in flower drop, decreasing fruit set and consequently decreasing fruit yield to a great extent. Vollenweider and Gunthardt-Goerg (2005) mentioned that at high temperature, the reproductive part of the flower is adversely affected. Stigma tube elongation, poor pollen germination, poor pollen tube growth and carbohydrate stress are the main reasons for poor fruit set at high temperature in tomato. Furthermore, Sato et al., (2000) reported that under high temperatures, fruit set in tomato plants failed due to disruption of sugar metabolism and transport during the narrow window of male reproductive development. Moreover, high temperature harmfully affects plant growth, survival and hence crop yield (Abd El-Mageed and Gruda, 2009).

With this perspective, it is noticed that hot and humid climates restrict the growing season for crop cultivation whereas, the growing season could be unlimited if the greenhouse air temperature and relative humidity could be adapted to a desired level for crops. Therefore, the aim of this research work is to investigate; 1) the performance of two cooled greenhouses by different evaporative cooling systems such as; Fan-Pad evaporative cooling system (control) and developed evaporative cooling system, (In the proposed cycle, the air is dried prior to entering the evaporative cooler. 2) the effect of both evaporative cooling system on the yield of tomato crop.

\section{MATERIALS AND METHODS}

\section{Materials}

\section{Greenhouses}

Two identical mechanically ventilated gable-even-span type greenhouses were utilized in summer seasons of 2014 and 2015 at El-Sabahia Horticultural Research Station, Alexandria. Each greenhouse has gross dimensions of $8.0 \mathrm{~m}$ long, $4.0 \mathrm{~m}$ wide and $3.1 \mathrm{~m}$ high. The two 
greenhouses are covered with single layer of polyethylene sheet of 200 $\mu \mathrm{m}$. Each greenhouse has three cultivation basins; each has the dimensions of $7.0 \times 0.80 \times 0.35 \mathrm{~m}$. Drip irrigation system was utilized for watering plants.

\section{Cooling Systems}

One greenhouse was equipped with the traditional pad-fan evaporative cooling system (control treatment), (FPECS) as shown in Fig. (1a). The cooling pad dimensions were $3.0 \mathrm{~m}$ long, 0.6 high and $0.1 \mathrm{~m}$ thickness with a face area of $1.8 \mathrm{~m}^{2}$. One suction fan (single speed, built driven, 60 $\mathrm{m}$ diameter and $8000 \mathrm{~m}^{3} / \mathrm{h}$ discharge) was located on the leeward side of the greenhouse, while the cooling pad was placed on the opposite side. The system was supplied with $0.5 \mathrm{hp}$ water pump discharges $24(\mathrm{~L} / \mathrm{h})$ to circulate water. The other greenhouse was equipped with an evaporative cooling unit, (Fig. 1b). The unit has a square base with the dimensions of $1.20 \times 1.20 \mathrm{~m}$ and $0.80 \mathrm{~m}$ height. The cooling unit has three openings from three sides, each $1.0 \times 0.6 \mathrm{~m}$ to hold the cellulose pad (three pieces each $1.0 \times 0.6 \times 0.1 \mathrm{~m}$ ). The three cellulose pads have a gross area of 1.8 $\mathrm{m}^{2}$ as the same area as the fan-pad system. The fourth side has an extracting fan that directly connected to a duct $0.35 \times 0.45 \mathrm{~m}$ and $1.0 \mathrm{~m}$ long to deliver the cooled air to the greenhouse. The water distribution system was located above the cellulose pad openings, which consists of three channels, $1.0 \mathrm{~m}$ long and $0.10 \mathrm{~m}$ wide with $3(\mathrm{~mm})$ holes $5 \mathrm{~cm}$ apart. It was supplied with 0.5 (hp) water pump to circulate water with a discharge rate of $24(\mathrm{~L} / \mathrm{min})$. There was also, a control valve to control the water flow rate over the cellulose pad. The base of the evaporative cooling unit has the dimensions of $1.20 \times 1.20 \times 0.10(\mathrm{~m})$ which forms a gross volume of 144 liters. It was acted as a water sump. The cooling unit was modified by coupling three residences of desiccant sieves, (Modified Evaporative Cooling System, MECS) is shown in Fig., 1c). The granules of silica gel were utilized as desiccant substance. Granule silica gel was bought from the Egyptian Chemical Stores. The silica gel was in spherical form, 2 to $5 \mathrm{~mm}$ diameter. The evaporative cooling unit supplies a rectangle duct of $7.0 \mathrm{~m}$ long with cross section $0.35 \times 0.45 \mathrm{~m}$ inside the greenhouse. It has $0.2 \times 0.2 \mathrm{~m}$ cross section windows and $0.50 \mathrm{~m}$ apart on 
each side. It is shown in Fig. (1d). The duct was hanged across the longitudinal axis of the greenhouse above the plant canopy to uniformly distribute the cooled air through the greenhouse. A schematic diagram of the whole system is illustrated in Fig. (2). When the silica gel sieves was moist to some extend it was replaced by another dry ones. The silica gel sieves then regenerated using a reactivation system as shown in Figure (3).

Tomato hybrid (Agiad 7) was utilized to investigate the effects of different macroclimatic conditions on fruit yield and quality. Seedling transplant was performed on $2^{\text {nd }}$ week of March in both 2014 and 2015 seasons, respectively

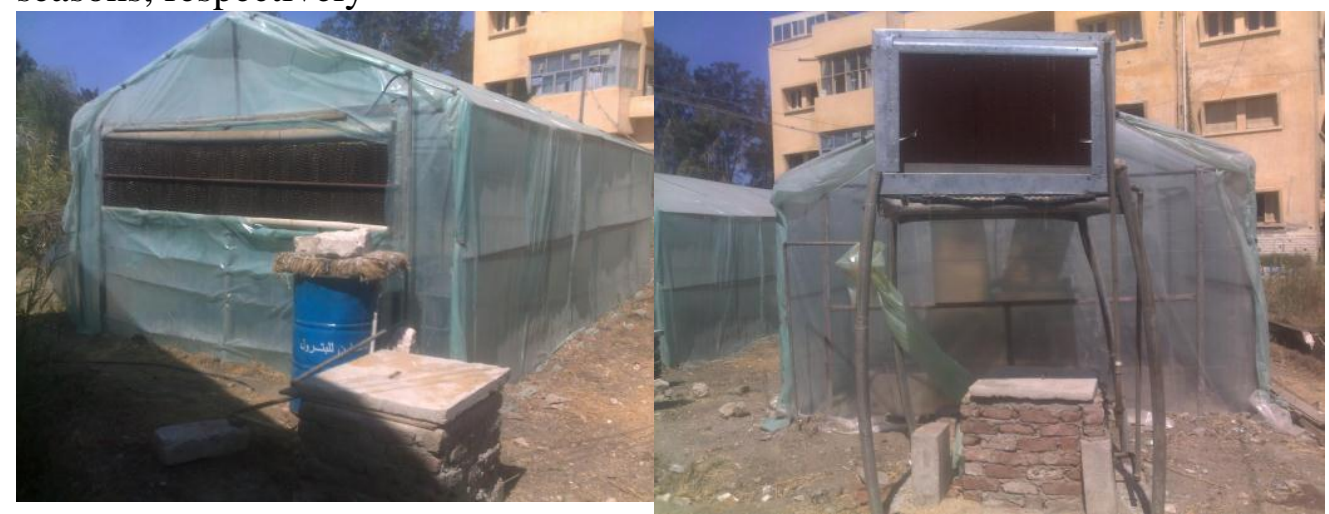

a- Fan-pad evaporative cooling b- Evaporative cooling unit system

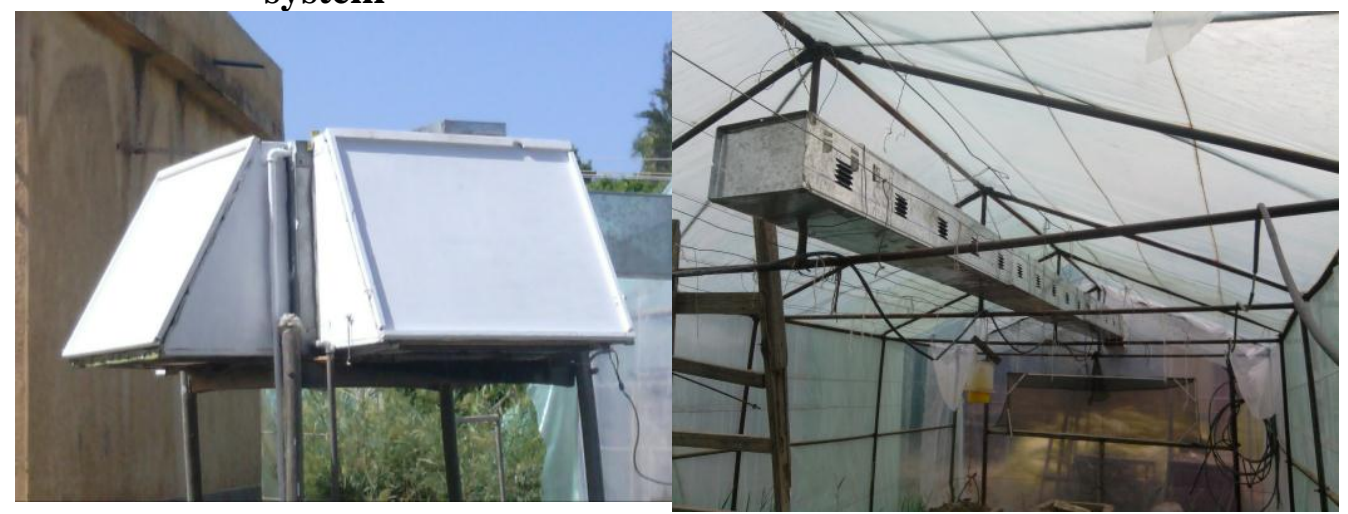

c- Modified evaporative cooling system with desiccant filter housings d- Perforated duct hanged across the greenhouse longitudinal axis

Fig. (1). The two evaporative cooling systems. 


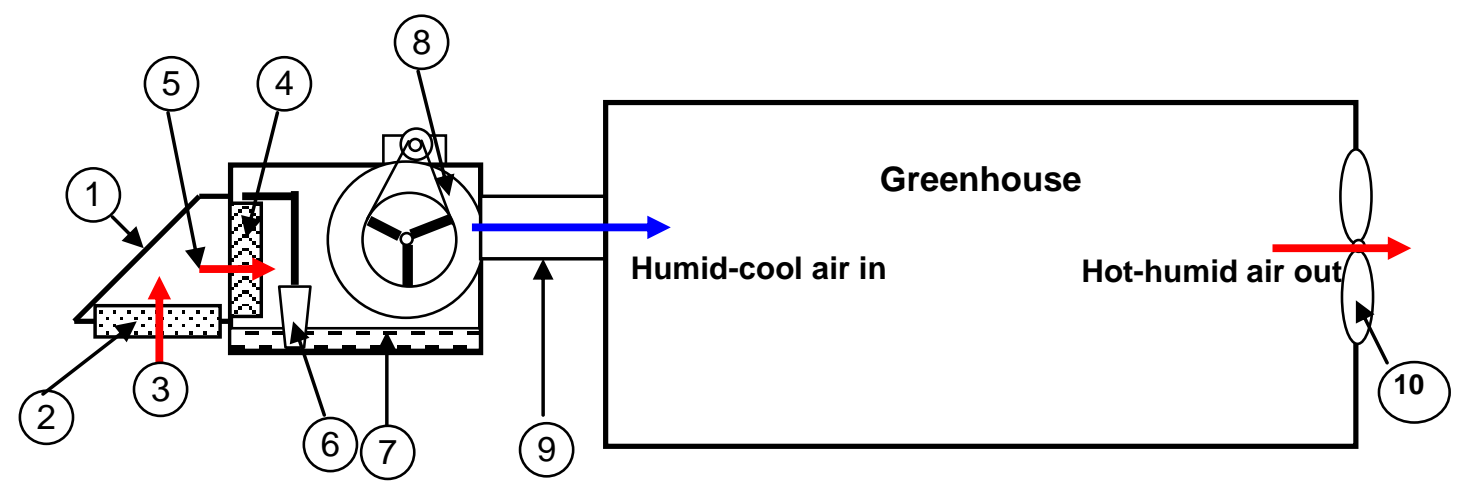

1- silica gel filter housing

2- silica gel sieve

4- cellulose pad

7- water sump
5- hot-dry air inlet

8- air blower
3- hot-humid air inlet

6- water pump

9- cool-humid air inlet

10- suction fan

Fig. (2). A schematic diagram of the developed evaporative cooling system with solid desiccant filters.

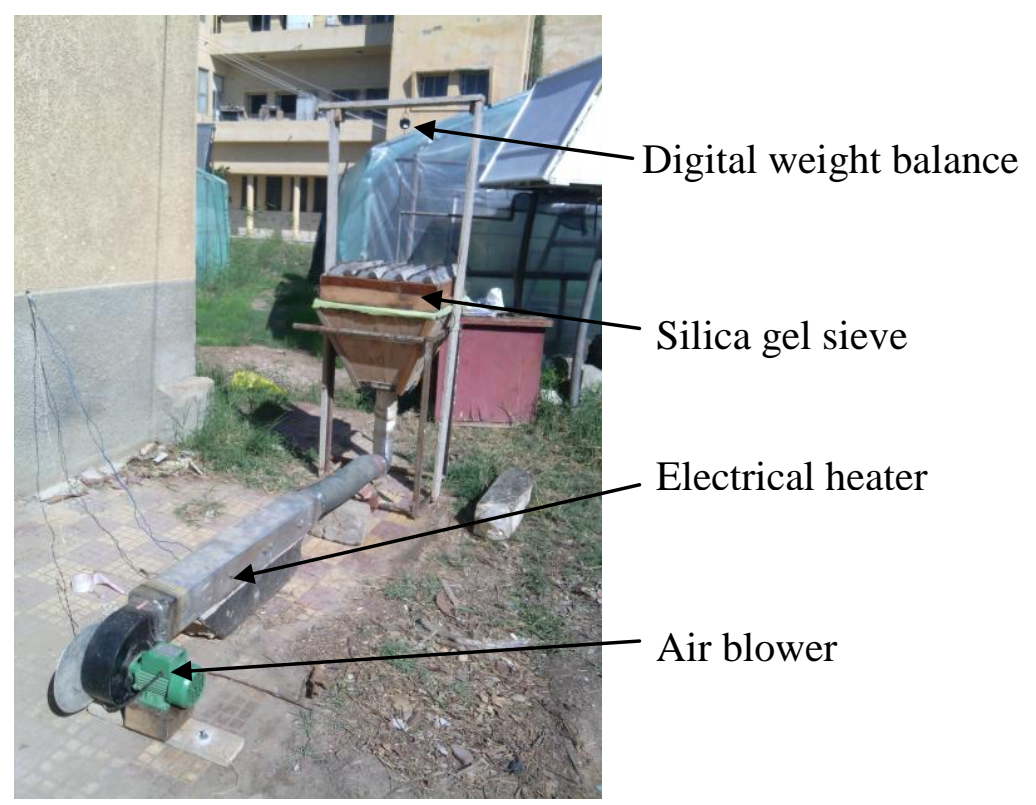

Figure (3). The silica gel regeneration system.

\section{Procedure and instrumentation}

The measurements were carried out from April to July of both 2014 and 
2015 seasons. The meteorological data from a meteorological station (5 KUE SKH 2013) included the measurements of solar radiation flux incident on a horizontal surface, dry-bulb air temperature, wind speed and its direction, and air relative humidity outside the greenhouses. The instruments used to measure theses variables were Pyranometer, ventilated thermistor, cup anemometer and wind vane, and hygrometer, respectively. The air temperatures and relative humidities prior and behind the desiccant sieve and after the cooling pad of the first greenhouse, prior and behind the cooling pads of the other one, with fifteen minutes intervals and the hourly average were recorded using Data-loggers type SATO, SK-L200 II- Japan. Microclimate variables within the greenhouses such as the temperature and relative humidity at the middle of the two greenhouses and just prior to the extracting fan were measured using thermocouple sensors type $\mathrm{K}$. These sensors were connected to a digital multimeter to record the data throughout the experimental period.

Random samples of five plants from each replicate were taken to determine the following characters:-

1) Early yield (kg\plant), 2) Total yield (kglplant), 3) Number of fruit per plant, 4) Average fruit weight (gm) and 5) Total yield (ton\feddan).

\section{Statistical analysis: -}

The collected data were statistically analyzed using the computer package program, SAS Ver.9.2 in order to obtain the least significant differences among treatments.

\section{Effectiveness of evaporative cooling system}

The efficiency of the evaporative cooling system is mainly associated with the cooling effect $\left(\mathrm{T}_{\mathrm{db}-\text { out }}-\mathrm{T}_{\mathrm{db} \text {-evp }}\right)$ and wet-bulb depression $\left(\mathrm{T}_{\mathrm{db}-\text { out }}-\right.$ $\mathrm{T}_{\text {wb-out }}$ ). The cooling efficiency $(\eta, \%)$ can be computed in terms of the cooling effect and the wet-bulb depression using the following equation (ASHRAE, 2010):

$$
\eta \quad=\frac{T_{d b-o u t}-T_{d b-e v p}}{T_{d b-o u t}-T_{w b-o u t}} \times 100,(\%)
$$


Where; $\mathrm{T}_{\mathrm{db} \text {-out }}$, is the air temperature prior to cooling pad in ${ }^{\circ} \mathrm{C}, \mathrm{T}_{\mathrm{db}-\text {-evp }}$, is the cooled air temperature just leaving the cooling pads in ${ }^{\circ} \mathrm{C}$, and, $\mathrm{T}_{\mathrm{wb}-\mathrm{out}}$, is the wet-bulb temperature of the air prior to the cooling pad in ${ }^{\circ} \mathrm{C}$.

Vapor pressure deficit of the greenhouse air (VPD) was calculated using Autogrow Spreadsheet Excel Software, (Autogrow, 2012). It expresses the combined interaction effect of the indoor dry-bulb temperature and relative humidity. To compute the VPD we need the greenhouse air temperature and the relative humidity. We must then compute the saturation pressure. Saturation pressure can be derived from the Arrhenius equation, (Shamshir et al., 2016) a way to compute it directly from temperature is:

$\mathrm{VPD}=\left(\mathrm{VP}_{\mathrm{sat}}-\mathrm{VP}_{\text {air }}\right) / 1000,(\mathrm{kPa})$

Where:

$$
\begin{aligned}
& \mathrm{VP}_{\text {sat }}=610.78 \exp \left(\frac{a(k-273.16)}{k-b}\right),(\mathrm{Pa}) \\
& \mathrm{VP}_{\text {air }}=0.01 \times \mathrm{RH} \times \mathrm{VP}_{\text {sat }},(\mathrm{Pa}) \\
& \mathrm{k}=\mathrm{T}\left({ }^{\circ} \mathrm{C}\right)+273.13, \text { Kelvin } \\
& \mathrm{a}=17.2693882 \text { and } \mathrm{b}=35.86 \text { are constant }
\end{aligned}
$$

\section{RESULTS AND DISCUSSIONS}

The main objective of the present study was to evaluate the performance of the microclimate of two greenhouses as affected by two evaporative cooling systems mainly modified evaporative cooling, (MECS) and fanpad, (FPECS) evaporative cooling systems. The optimization of air temperature, relative humidity, and vapour pressure deficit in greenhouses are particularly important in relation to plant growth, development, and productivity. In order to achieve optimum greenhouse conditions, it is necessary to ventilate and cool the greenhouse, particularly during the hot season.

\section{Effect of weight of silica gel on the amount of grasped moisture and time needed for air to reach $30 \%$ relative humidity}

Pre-experiments were performed to find out the optimal silica gel weight required to dehumidify the ambient air before passing throughout the 
cooling pad. Three weights of silica gel were utilized; 15.0, 25.0 and 30.0 $\mathrm{kg}$ for each sieve. The acceptable range of relative humidity of the air out of the desiccant sieves should be ranged from 0.0 to $30.0 \%$ throughout the experimental work as recommended. This was to attain maximum cooling efficiency by simulating the Desert condition (dry weather). The silica gel sieves were replaced with regenerated ones when the relative humidity of passing air reached $30 \%$. Calculating the correct quantity of silica gel allows for the cost-efficient selection of an appropriate amount of buffering material.

The average times needed by different weights of silica gel to achieve the maximum acceptable air relative humidity, (30\%) and the average grasped moistures were demonstrated in Fig. (4). The average times were 56.0, 70.0 and 95.0 minute for $15.0,25.0$ and $30.0 \mathrm{~kg}$ silica gel, respectively. The percentage increases in air dehumidifying time over $15.0 \mathrm{~kg}$ weight were 25.0 and $69.64 \%$. The average weights of grasped moisture were $102.3,138.8$ and 153.2 gram moisture $/ \mathrm{kg}$ silica for 15.0, 25.0 and $30.0 \mathrm{~kg}$ silica gel, respectively. Whereas, the percentage increases in grasped moisture over the $15.0 \mathrm{~kg}$ weight were 35.68 and 49.71\%. These results are in harmony with those of Afonso and Silveirea (2005) they concluded that the amount of moisture adsorbed by silica gel was ranged between 7.0 and $209.0 \mathrm{~g} / \mathrm{kg}$ depending on the surrounding air relative humidity.

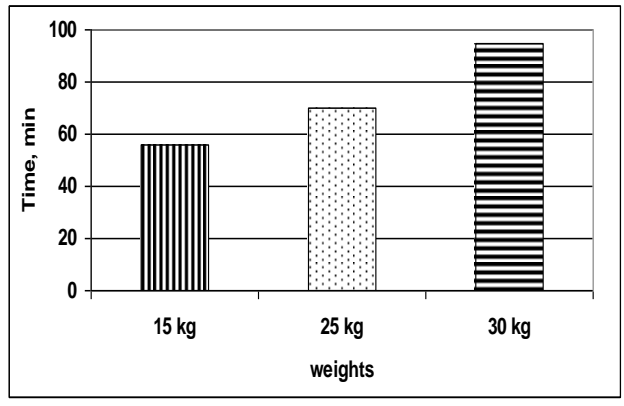

a- average time

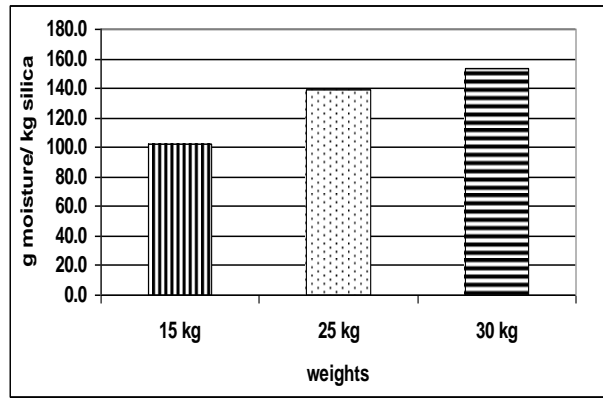

b- average grasped moisture

Fig. (4). Effect of different weights of silica gel on the average times and amounts of grasped moisture. 
Results revealed that the three weights of silica gel were able to absorb the moisture of the ambient air but the replacement times were significantly differed. Subsequently, the system was operated during this experimental work utilizing $30 \mathrm{~kg}$ for each sieve to reduce the labor of replacing the silica gel sieves and reducing the number of replacement during the day.

\section{Microclimate data of the weather station outside the two greenhouses}

The hourly averages solar radiation flux incidents outside the greenhouses, ambient air temperatures and relative humidities throughout three successive days are illustrated in Fig. (5a and 5b). The solar radiation incident at or around noon reached the level of more than 1000 $\mathrm{W} / \mathrm{m}^{2}$, ambient air temperature was exceeding $33.0{ }^{\circ} \mathrm{C}$ while relative humidity did not fall down the level of $55 \%$ in the experimental location, (Sabahia, Alexandria) as a humid costal region. The hourly averages solar radiation flux incident outside the greenhouses were 513.1, 598.9, 645.3, and $631.4 \mathrm{~W} / \mathrm{m}^{2}$ for April, May, June, and July, respectively. While, this amount recorded inside the greenhouse during the same time was 267.7, 344.3 , 465.3, and $433.8 \mathrm{~W} / \mathrm{m}^{2}$, respectively. Consequently, the hourly average effective transmittances of the polyethylene cover were $67.1 .53 \%, 69.9 \%, 72.1 \%$, and $69.7 \%$, respectively.

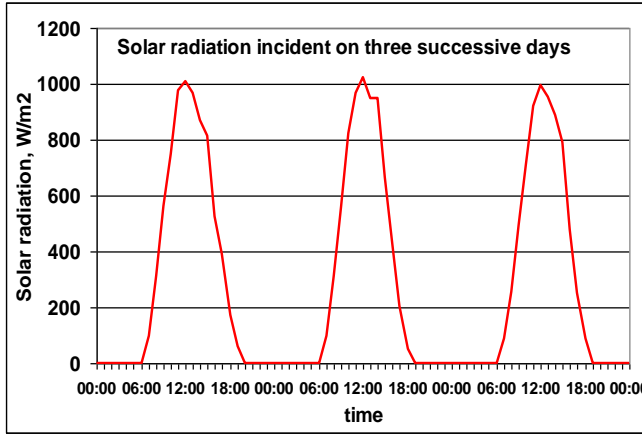

a- Solar irradiance

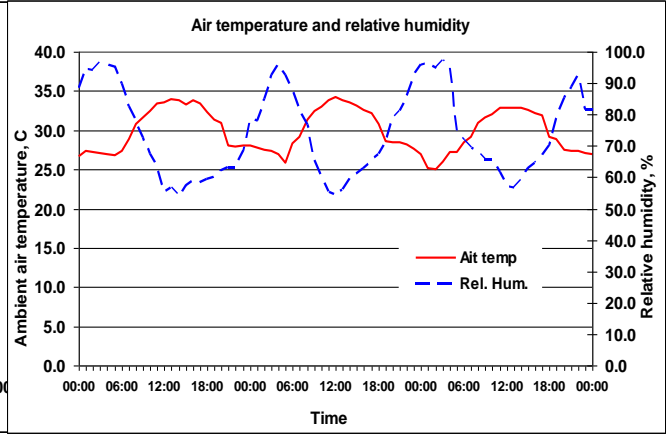

b- Air temperature and relative humidity

Fig. (5). The solar intensity, ambient air temperature and relative humidity of three successive days in the experimental location, Sabahia-Alexandria. 
3. Effects of both cooling systems on the indoor temperatures of greenhouses

To show the effect of both evaporative cooling systems on greenhouse temperatures, data were demonstrated for an excessive solar intensity day $\left(\mathrm{SR}>1000 \mathrm{w} / \mathrm{m}^{2}\right)$, very hot $\left(>30.0{ }^{\circ} \mathrm{C}\right)$ and humid $(>55 \%)$. The solar radiation incident, (SR), ambient air temperatures outside the two greenhouses, $\left(\mathrm{T}_{\mathrm{o}}\right)$, the temperatures of air jest leaving the cool pad for both modified evaporative cooling system, ( $\left.T_{\text {evp-MECS }}\right)$, and fan-pad evaporative cooling system ( $\left.\mathrm{T}_{\text {evp-FPECS }}\right)$ and the indoor temperatures for both greenhouses, $\left(\mathrm{T}_{\text {gr-MECS}}\right)$ and $\left(\mathrm{T}_{\text {gr-FPECS }}\right)$ were illustrated in Fig. (6a and $6 b)$.

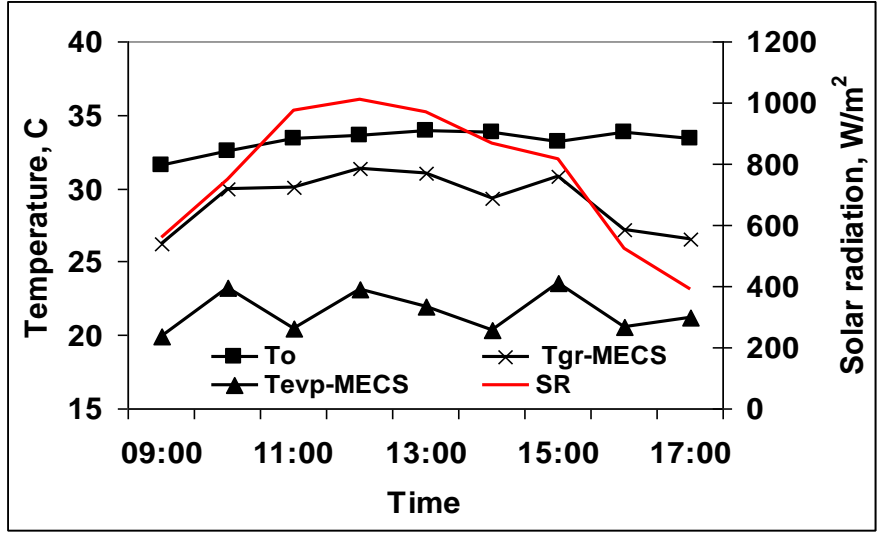

a- The performance of MECS greenhouse

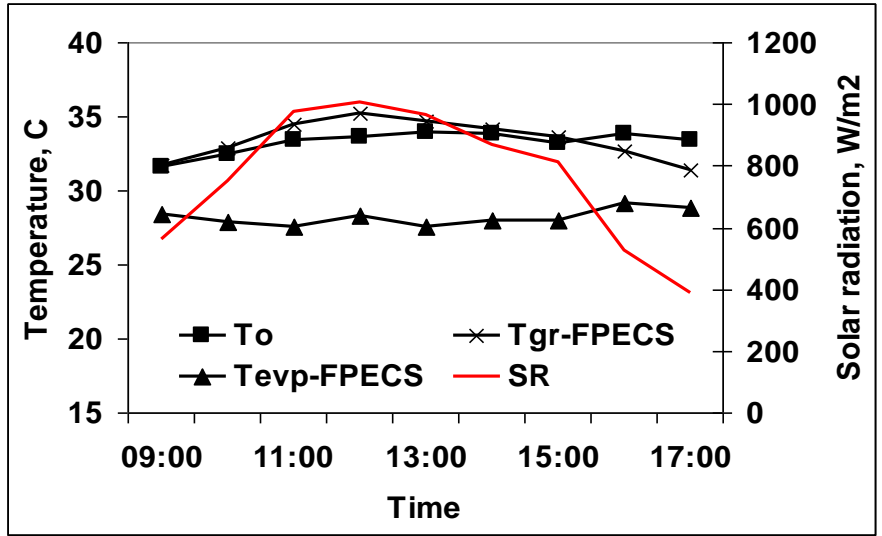

b- The performance of FPECS greenhouse

Fig (6). The Solar radiation incident, $(S R)$ ambient temperature, $\left(T_{0}\right)$, the temperature of air just leaving the cool pad for both MECS, $\left(T_{\text {evp }}\right.$ MECS) and FPECS ( $\left.T_{\text {evp-FPECS }}\right)$ and the air temperatures for both greenhouses, $\left(T_{\text {gr-MECS }}\right)$ and $\left(T_{\text {gr-FPECS }}\right)$. 
The figure showed that the temperatures of air just leaving the cooling pad for MECS greenhouse were ranged from 19.9 to $23.5{ }^{\circ} \mathrm{C}$ with an average of $21.6{ }^{\circ} \mathrm{C}$. On the other hand, those of FPECS greenhouse were ranged from 27.6 to $29.1{ }^{\circ} \mathrm{C}$ with an average of $28.2{ }^{\circ} \mathrm{C}$. It is obviously clear the effect of interrupting the ambient air by the silica gel sieve to firstly grasp the moisture from the ambient air prior to passing through the cooling pad. Consequently, the inside air of MECS greenhouse temperatures were ranged from 26.3 to $31.4{ }^{\circ} \mathrm{C}$ with an average of 29.2 ${ }^{\circ} \mathrm{C}$. On the other hand, those of FPECS greenhouse were ranged from 31.4 to $35.2{ }^{\circ} \mathrm{C}$ with an average of $33.4{ }^{\circ} \mathrm{C}$. Also, the indoor temperatures of the MPECS greenhouse were decreased than the outside ambient temperature specially, at and around noon time by $2.9^{\circ} \mathrm{C}$. On the other hand, the indoor temperatures of FPECS greenhouse exceeded the outside ambient temperature at and around noon time by $1.64{ }^{\circ} \mathrm{C}$.

Shamshiri and Ismail, (2014) suggested that integrated scheduling of natural and mechanical ventilation with appropriate cooling techniques in peak-hours can efficiently manipulate greenhouse environment.

\section{Understanding the evaporative cooling process on psychometric chart}

The cooling process can be explained on the psychometric chart to understand the cooling effect, wet-bulb depression and evaporative cooling efficiency for the two evaporative cooling systems. The cooling processes for both evaporative cooling systems were illustrated in Fig. (7).

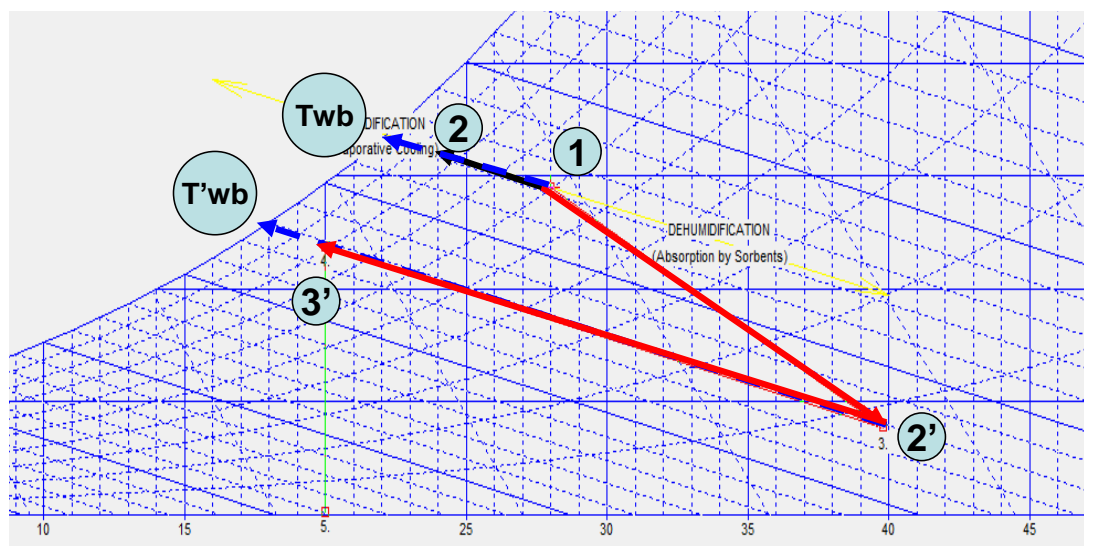

Fig. (7). The cooling processes of both evaporative cooling systems 
The cooling effect is the difference between the temperatures of outside dry bulb ( $\left.\mathrm{T}_{\mathrm{db}-\mathrm{out}}\right)$ and temperature just leaving the cooling pad $\left(\mathrm{T}_{\text {evp }}\right)$. The wet-bulb depression is the difference between the dry and wet bulb $\left(\mathrm{T}_{\mathrm{wb}}\right.$ out) temperatures of outside air. It is expected that the cooling effect is a fraction of wet-bulb depression. The state of ambient air was point 1 . The cooling process for FPECS was explained by points 1,2 and $\mathrm{T}_{\mathrm{wb}}$. The cooling effect is the distance between points 1 and 2. (i.e. $28-24=4{ }^{\circ} \mathrm{C}$ ), while, the wet-bulb depression was the distance between points 1 and $\mathrm{T}_{\mathrm{wb}}$ (i.e. $28-22=6{ }^{\circ} \mathrm{C}$ ). So, the efficiency was $66.67 \%$. On the other hand, for the developed evaporative cooling system, the cooling process is

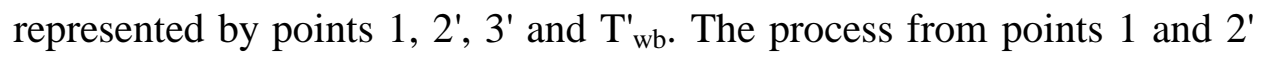
was dehumidifying the ambient air by the silica gel, but unfortunately this is a heat release process, so the temperature of the ambient air was increased while the relative humidity was deceased. Hence, the cooling effect is the distance between points $2^{\prime}$ and $3^{\prime}$ (i.e. 40.0-19.5=20.5 C) whereas; the wet-bulb depression is the distance between points $2^{\prime}$ and $\mathrm{T}_{\mathrm{wb}}$ (i.e. $40.0-17.5=22.5$ ). Consequently, the efficiency was $91.1 \%$. Hence, the percent increase was $36.64 \%$ in the efficiency of MECS over FPECS.

\section{The cooling effect of both evaporative cooling and the wet-bulb depression.}

The dry-bulb and wet-bulb of ambient air, and the temperatures of air just leaving the cooling pads of the two evaporative cooling systems were demonstrated in Fig. (8). It is regular that the temperatures just leaving the cooling pad of FPECS were greater than the wet-bulb temperatures of outside air whereas, the system efficiency was lower than 100\%. This result was reported with Garzoli, (1989) who mentioned that direct evaporative cooling can not achieve temperatures lower than the ambient wet-bulb temperature and the achieved temperatures were actually higher than the wet-bulb temperature. On the other hand, the temperatures just leaving the cooling pad of MECS were lower than the ambient wet-bulb temperature. Hence, it is important to obstruct the humid air by the silica gel sieve prior to passing through the cooling pad to dry it. Consequently, the air moisture was partially removed causing a decrease in the air 
relative humidity and wet bulb temperature compared with the outside one. So, the temperature of the air just leaving the cooling pad of MECS was lowered than the ambient web-bulb temperature. The average temperatures of air just leaving the cooling pad were 21.6 and $28.2{ }^{\circ} \mathrm{C}$ for MECS and FPECS, respectively for the averages outside ambient air temperatures and relative humidity of $32.2{ }^{\circ} \mathrm{C}$ and $62.8 \%$, respectively.

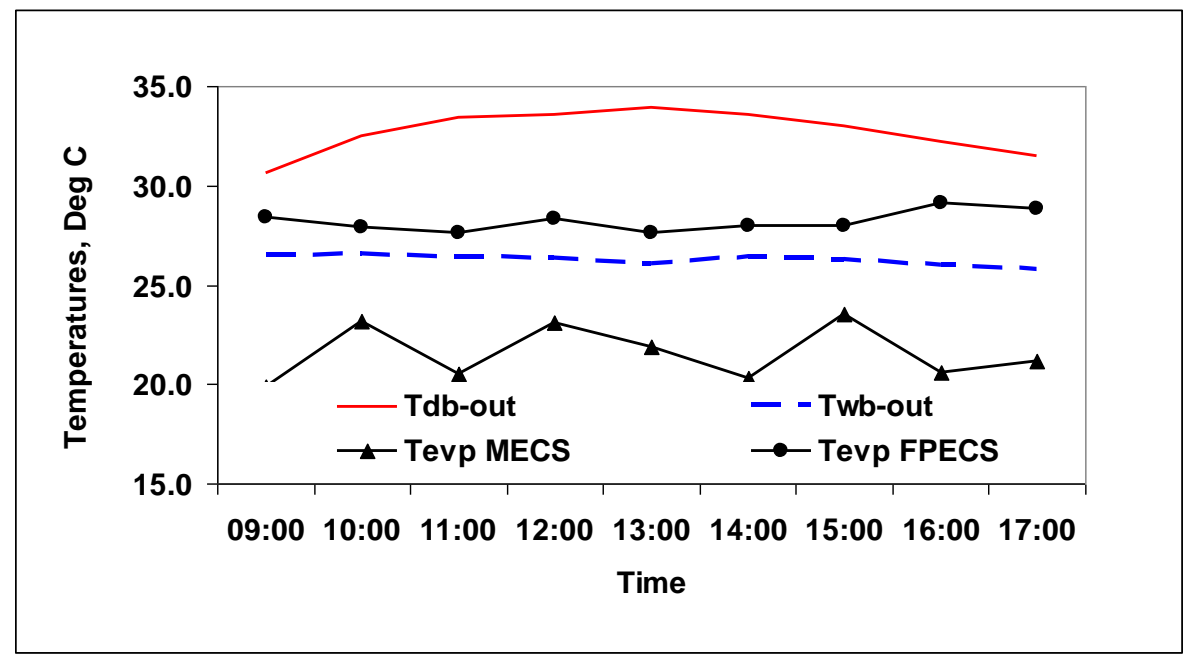

Fig. (8). The outside dry, wet-bulb temperatures, and the temperatures of air just leaving the cooling pad of both evaporative cooling systems.

The percentage decrease in the temperature just leaving the cooling pad for MECS over FPEVS was 30.30\%. The results of MECS are in agreement with Vox et al., (2010) who mentioned that the outside air temperature can be reduced by as much as 10 to $25^{\circ} \mathrm{C}$ cooler than ambient temperature in regions with very low humidity.

The cooling effects of both FPECS and MECS were plotted with the wetbulb depression (dry bulb - wet bulb) of the outside ambient air in Fig. (9). The figure clearly proved that the cooling effect of FPECS was always lower than the wet-bulb depression of ambient air. On the other hand, the cooling effect of the MECS was estimated from the temperature of air after passing on the silica gel minus the temperature of air after the cooling pad. The results of the MECS showed that the cooling effect is 
greater than the wet-bulb depression of ambient air. Hence, the importance of interrupting the air stream by the silica gel sieve in the proposed MECS. A greater decrease in temperature of ambient air was achieved after passing on the silica gel sieve in addition to passing on the cooling pad of the evaporative cooling. Consequently, greater cooling effect was occurred. The averages of cooling effect were 11.25 and 4.69 ${ }^{\circ} \mathrm{C}$ for MECS and FPECS, respectively.

These results were in line with Mehmet and Hasan (2015) they found that the hourly mean cooling effect for fan-pad system was $6.96^{\circ} \mathrm{C}$.

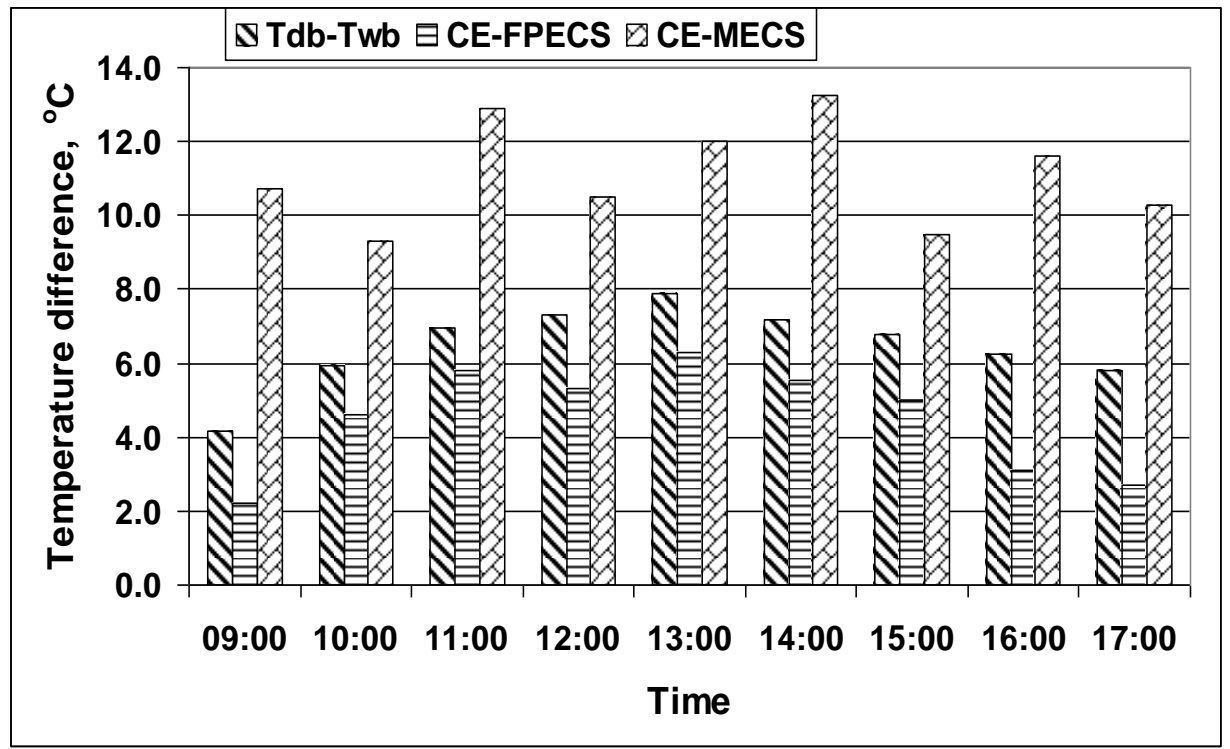

Fig. (9). The wet bulb depression against the actual cooling effect by the two evaporative cooling systems

\section{Evaporative cooling efficiency}

The efficiencies of both evaporative cooling systems in both days were demonstrated in Fig. (10). The figure showed the expected increase in MECS efficiency than the FPECS. The minimum, maximum and average efficiencies were (85.1, 92.1 and 89.6\%) and (57.4, 67.0 and 62.1\%) for MECS and FPECS systems, respectively. The MECS possess an increase by $44.40 \%$ over FPECS. 


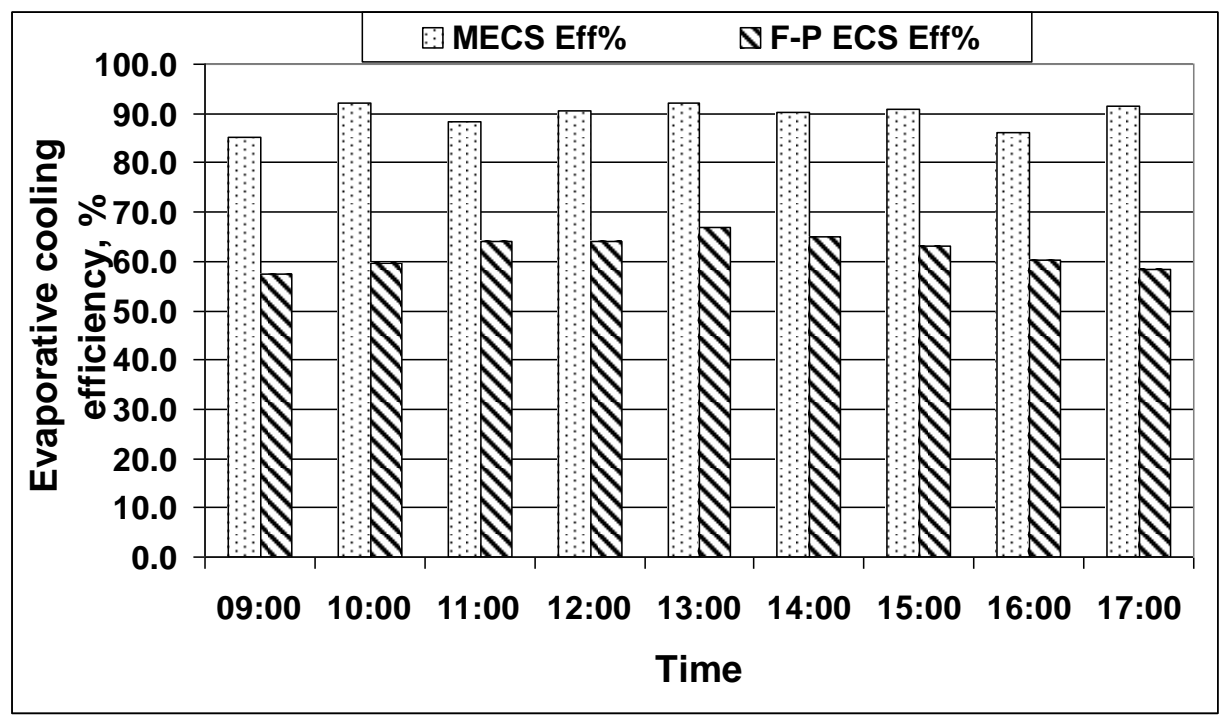

Fig. (10). The efficiency of both evaporative cooling systems

Mehmet and Hasan (2015) reported that the hourly mean cooling efficiency for fan-pad system was found to be $76.8 \%$. In addition, Abdellatif et al., (2010) found that the daily average effectiveness of the fan-pad evaporative cooling system was $76.6 \%$.

\section{The indoor relative humidity in both greenhouses}

The indoor relative humidity in both greenhouses is presented in Fig. (11). The relative humidities of FPECS greenhouse showed an increase in greenhouse indoor relative humidity than MECS greenhouse. The decrease in relative humidity of MECS greenhouse may be due to the dryness of air out of the silica gel sieve, whereas the air was already partially saturated as a humid region before passing through the FPECS cooling pad. Also, more wetting was occurred by the cooling pad. The minimum, maximum and average relative humidities were $(57.2,76.9$ and $65.2 \%)$ and $(63.7,82.6$ and $71.4 \%)$ for MECS and FPECS greenhouses, respectively. The percentage increases in the average relative humidity of FPECS greenhouse was 9.38 over MECS one. It is often recommended that greenhouse relative humidity must be maintained in the range of $60 \%$ to $80 \%$ for healthy growth. 


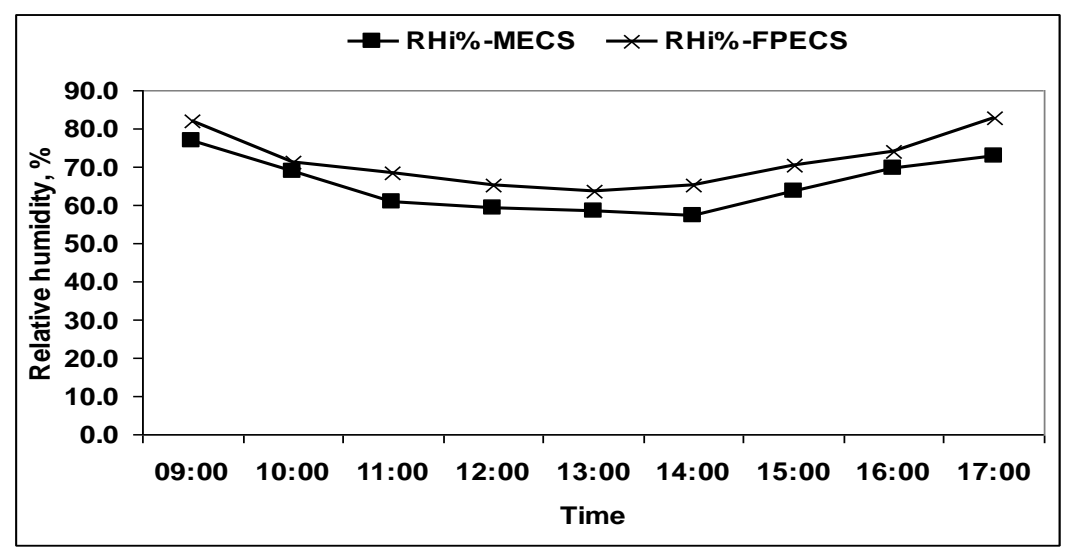

Fig. (11).The indoor air relative humidities in both greenhouses.

At high levels of relative humidity, the risk for condensation on leaves is high (especially at night). Thus, the risk of Botrytis and other fungal diseases would increase, Vox et al., (2010). Several studies also (Argus, 2009) showed that, under evaporative cooling using fan-pad system, the air relative humidity at the critical period was ranged from 48.6 to $51.8 \%$ which was lower than the optimal level (65\%). Therefore, the air relative humidity must be raised to $65 \%$ at that period by increasing the water flow rate on the cooling pads

\section{The vapor pressure deficits (VPD) of the two greenhouses}

The vapor pressure deficits of the two greenhouses as affected by the two evaporative cooling systems were illustrated in Table (1).

Table (1). The indoor air temperatures, relative humidities and vapor pressure deficits of both greenhouses.

\begin{tabular}{ccccccc} 
& \multicolumn{2}{c}{ MECS greenhouse } & \multicolumn{3}{c}{ FPECS greenhouse } \\
& $\begin{array}{c}\mathbf{T}_{\mathbf{g r}} \\
\text { Time }\end{array}$ & $\begin{array}{c}\left.\mathbf{R H}_{\mathbf{~}} \mathbf{C}\right) \\
(\mathbf{\%})\end{array}$ & $\begin{array}{c}\text { VPD } \\
(\mathbf{k P a})\end{array}$ & $\begin{array}{c}\mathbf{T}_{\mathbf{g r}} \\
\left({ }^{\mathbf{C}}\right)\end{array}$ & $\begin{array}{c}\mathbf{R H}_{\mathbf{g r}} \\
(\boldsymbol{\%})\end{array}$ & $\begin{array}{c}\text { VPD } \\
(\mathbf{k P a})\end{array}$ \\
\hline $\mathbf{0 9 : 0 0}$ & 26.3 & 76.9 & $\mathbf{0 . 7 9}$ & 31.7 & 82.1 & $\mathbf{0 . 8 2}$ \\
$\mathbf{1 0 : 0 0}$ & 28.9 & 68.7 & $\mathbf{0 . 9 2}$ & 32.9 & 71.1 & $\mathbf{1 . 4 5}$ \\
$\mathbf{1 1 : 0 0}$ & 29.0 & 60.7 & $\mathbf{1 . 5 8}$ & 34.5 & 68.3 & $\mathbf{1 . 7 3}$ \\
$\mathbf{1 2 : 0 0}$ & 30.4 & 59.4 & $\mathbf{1 . 7 6}$ & 35.2 & 65.0 & $\mathbf{1 . 9 9}$ \\
$\mathbf{1 3 : 0 0}$ & 30.0 & 58.4 & $\mathbf{1 . 7 7}$ & 34.6 & 63.7 & $\mathbf{2 . 0 0}$ \\
$\mathbf{1 4 : 0 0}$ & 29.3 & 57.2 & $\mathbf{1 . 7 5}$ & 34.2 & 65.0 & $\mathbf{1 . 8 8}$ \\
$\mathbf{1 5 : 0 0}$ & 28.8 & 63.5 & $\mathbf{1 . 4 4}$ & 33.6 & 70.2 & $\mathbf{1 . 5 5}$ \\
$\mathbf{1 6 : 0 0}$ & 27.2 & 69.4 & $\mathbf{1 . 1 1}$ & 32.6 & 74.1 & $\mathbf{1 . 2 7}$ \\
$\mathbf{1 7 : 0 0}$ & 26.6 & 72.9 & $\mathbf{0 . 9 4}$ & 31.4 & 82.6 & $\mathbf{0 . 8 0}$ \\
\hline Avg & $\mathbf{2 9 . 2}$ & $\mathbf{6 5 . 2}$ & $\mathbf{1 . 3 9}$ & $\mathbf{3 3 . 4}$ & $\mathbf{7 1 . 4}$ & $\mathbf{1 . 5 0}$ \\
\hline
\end{tabular}


The data in the table indicated that the minimum, maximum and average VPD were $(0.79,1.77$ and $1.39 \mathrm{kPa})$ and $(0.80,2.00$ and $1.50 \mathrm{kPa})$ for MECS and FPECS, respectively. It also, showed that the dangerous value of VPD was 2.0 KPa which was achieved at 13:00 once only by FPECS greenhouse. The obtained results of air vapor pressure deficit inside the two greenhouses revealed that the VPD was higher than the higher optimum level (VPD $<1.425 \mathrm{kPa}$ ) at and around noon. Thus, the greenhouses climatic conditions should be kept underneath $1.425 \mathrm{kPa}$ to avoid injury and death of tomato plant. It is noticeable that MECS greenhouse achieved lower values of VPD than FPECS greenhouse at the same time. The higher values of VPD means that air had a higher capacity to hold moisture, stimulating water vapor transfer i.e more transpiration into the air whereas, lower VPD on contrary means the air was at or near saturation, so the air cannot accept moisture from plant leaf. This results showed more decrease in the VPD values than those mentioned by Abdellatif et al., (2010) who noted that protected cultivation of vegetable crops in Egypt during summer season were exposed to high humidity, massive intensity of solar radiation, air temperature and high vapour pressure deficit during that period. The hourly averages vapour pressure deficit inside the greenhouse equipped with fan-pad system were 1.53, $1.75,1.83$, and $1.53 \mathrm{kPa}$ for April, May, June and July, respectively.

\section{The effect of microclimate conditions on tomato yield.}

Effect of macroclimate conditions on early and total fruit yield and yield components were demonstrated in Table (2). The data demonstrated in Table (2) indicated that all investigated characters such as; early yield, number of fruit per plant, fruit weight, total yield per plant and total yield per feddan positively improved due to enhancing the macroclimate conditions of MECS greenhouse in both seasons. The percentages increase in early yield, number of fruit per plant, fruit weight, total yield per plant and total yield per feddan were 14.07, 9.43, 8.00, 18.15 and $18.13 \%$, respectively for MECS greenhouse over FPECS greenhouse in 2014 season, while they were $12.41,12.98,7.90,22.06$ and $21.97 \%$, respectively in 2015 season. 
Table (2). Effect of macroclimate conditions on early, fruit yield and yield components in both greenhouses in both seasons.

\begin{tabular}{|c|c|c|c|c|c|}
\hline GH & $\begin{array}{c}\text { Early yield } \\
\text { (Kg/pl) }\end{array}$ & $\begin{array}{c}\text { No. } \\
\text { fruit/PI }\end{array}$ & $\begin{array}{c}\text { Fruit } \\
\text { weight } \\
\text { (g) }\end{array}$ & $\begin{array}{c}\text { Yield/ } \\
\text { Plant } \\
\text { (kg) }\end{array}$ & $\begin{array}{l}\text { Yield/ fed } \\
\text { (ton/fed) }\end{array}$ \\
\hline \multicolumn{6}{|c|}{ Season 2014} \\
\hline MECS & 1.54 & $\begin{array}{l}70.19 \\
\end{array}$ & 162 & $\begin{array}{l}11.39 \\
\end{array}$ & 46.71 \\
\hline FPECS & 1.35 & 64.14 & 150 & 9.64 & 39.54 \\
\hline $\mathbf{L S D}_{0.05}$ & 0.097 & 2.01 & 5.94 & 0.60 & 2.47 \\
\hline \multicolumn{6}{|c|}{ Season 2015} \\
\hline MECS & 1.63 & 74.14 & 164.38 & 12.23 & 50.13 \\
\hline FPECS & 1.45 & 65.62 & 152.34 & 10.02 & 41.10 \\
\hline $\mathbf{L S D}_{0.05}$ & 0.08 & 2.1 & 5.63 & 0.64 & 2.63 \\
\hline
\end{tabular}

These results in line with that mentioned by Jones, (2007), that tomato yields are primarily affected by the climate conditions with highest yields belonging to greenhouse in which have moderate cool air temperature. Also, Hurd and Graves, (1985) reported that elevating the temperature often increases the fruit growth rate, but it has a greater effect in hastening maturity and, as a result, the final mean weight of tomato fruits is reduced. These results is also, in harmony with those obtained by Islam (2011) who reported that number of fruits/plant, individual fruit weight and fruit yield/plant significantly decreased at $32^{\circ} \mathrm{C}$ temperature at preflowering and flowering stages. Tomato grows under high temperature produced lower fruit yield (Ho 1996; Adams et al,. 2002). Lower fruit yield under high temperature is mainly due to limiting carbohydrate supply. The optimum fruit growth and development occur when night temperature is between 15 and $20^{\circ} \mathrm{C}$ and the day temperature at about $25^{\circ} \mathrm{C}$ (Kalloo 1985). Also, Nguyen et al., (2015) stated that greenhouse coverage protects plants from adverse atmospheric agents and, together with suitable equipment, influences and ultimately modifies the crop microclimate, thus lengthening the market availability of the products, improving their quality and allowing higher yields. High temperatures during the growing season have been reported to be detrimental to growth, reproductive development and yield of several crops (Hussain $\boldsymbol{e t}$ al., 2006 Singh et al., 2007). 


\section{CONCLUSION}

The output results of this research work indicated that obstructing the incoming ambient air by the silica gel sieves enhanced the performance of the evaporative cooling system. So, the macroclimate of the MECS greenhouse was much comfortable for tomato plant than the greenhouse of the FPECS.

\section{RECOMMENDATION}

Desiccant wheel must be introduced into the system instead of the silica gel sieve to reduce the labor of hand work. Also, solar energy regeneration system should be utilized to conserve energy for reactivation.

\section{REFERENCES}

Abd El-Mageed, A.H.A. and N. Gruda (2009). Performance of different tomato genotypes in the arid tropics of Sudan during the summer season. II. Generative Development. Journal of Agriculture and Rural Development in the Tropics and Subtropics. 110(2): 147-154. Abdellatif, S.M., M.M.M. Ibrahim and M.M.H. El-Lithy (2010). A comparative study on two different evaporative cooling systems for producing cucumber crop under hot-humid summer conditions. J. Soil Sci. and Agric. Eng., Mansoura Univ., 1 (10):1015-1036.

Adams, S.R., K.E. Cockshull and C.R.J. Cave (2002). Effect of temperature on the growth and development of tomato fruits. Annals Bot. 88, 869-877.

Adil, A.H.; N. Gruda, and B. Geyer (2004). Effects of temperature and grafting on the growth and development of tomato plants under controlled conditions. Rural poverty reduction through research for development and transformation, berlin, October 5-7, 2004.

Afonsoa, M.R.A. and V. Jr. B. Silveira (2005). Characterization of equilibrium conditions of adsorbed silica-gel/water bed. according to Dubinin-Astakhov and Freundlich. Engenharia Térmica (Thermal Engineering), 4(1): 3-7.

Argus, (2009). Understanding and Using VPD. Argus Control System LTD www.agruscontrols.com, Canada V4B 3 Y9. 
ASHRAE, (2010). Psychrometrics, American Society for Heating, Refrigeration, and Air Conditioning Engineers Fundamentals. SI Ed. Atlanta, USA. Ch 6: 6.1-6.17,

Autogrow, (2012). Vapour Pressure Deficit Calculator in Excel Spreadsheet, Autogrow System Ltd. (www.autogrow.com)

Bhatia, A. B.E. (2012). Principles of Evaporative Cooling System. PDHonline Course M231 (4 PDH). pp. 56. www.PDHonline.org

Bora, A., P. Saini, R. Bora, S. R. Purohit, A. Bora and S. K. Tripathy (2017). Desiccant evaporative cooling system. Intern. J. of Sci. Develop. and Res., (IJSDR), April 2017, 2 (4): 232-335.

Bourouni, K. (2008). Greenhouses Cooling: intelligent technologies using direct contact heat exchangers and challenges of desiccants. Atelier Mediterraneen sur les Nouvelles Technologies de Recyclage des Eaux Non Conventionnelles dans les cultures protégées 28 Avril - 1er Mai 2008.

Davies, P.A. (2005). A solar cooling system for greenhouse food production in hot climates. Solar Energy, 79 : 661-668.

El-Bakhashwan, M.K., G.D.M. Youssef, Salwa S. Hanna and Sh.M. Abdel-Ghafar (2013). Solar energy utilization for regeneration of moist silica gel. Egyptian J. of Agric. Res. $3^{\text {rd }}$ International Conference for Agricultural and Bio-Engineering. (Engineering Application for Sustainable Agricultural Development) - 24 Nov. 2013. 91 (2 B) $647-671$.

Evaptainers, (2014). The Science of Evaporative Cooling. http://www.Evaptainers .com /updates/2014/8/6/the-sciance-ofevaporative-cooling, August 7, 2014.

Farmahini, F. M.; S. Delfani and J. Esmaeelian (2012). Exergy analysis of evaporative cooling to select the optimum system in diverse climates. Energy, 40: 250-257

Franco, A., D.L. Valera, and A. Peña (2014). Energy efficiency in greenhouse evaporative cooling techniques: Cooling boxes versus cellulose pads. Energies, 2014, 7: 1427-1447.

Garzoli, K.V. (1989). Cooling of greenhouses in tropical and sub-tropical climates. Acta Horticult. 257: 93-100. 
Ho, L.C. (1996). The mechanism of assimilate partitioning and carbohydrate compartmentalization in fruit in relation to the quality and yield of tomato. J. Exp. Bot. 47: 1239-1243.

Hurd, R.G. and C.J. Graves (1985). Some effects of air and root temperatures on the yield and quality of glasshouse tomatoes. Journal of Horticultural Science 60: 359-371.

Islam, M.T. (2011). Effect of temperature on photosynthesis, yield attributes and yield of tomato genotypes. Int. J. Expt. Agric. 2(1):811, (January 2011)

Jamaludin, Diyana; D. Ahmad; R. Kamaruddin; and H.Z.E. Jaafar (2014). Microclimate inside a tropical greenhouse equipped with evaporative cooling pads. Pertanika J. Sci. \& Technol., 22 (1): 255 - 271 (2014).

Jones, Jr. B. (2007). Tomato Plant Culture: In the Field, Greenhouse, and Home Garden, $2^{\text {nd }}$ Boca Raton, FL: CRC Press. Taylor \& Francis Group, LLC.

Joudi, Kh.A. and M.M. Hasan (2013). Cooling and heating a greenhouse in Baghdad by a solar assisted desiccant system. J. Eng., 933, 8 (19) 933-951.

Kalloo, D. (1985). Tomato. Allied Publishers Private Ltd. 13/14 Asaf Ali Road, New Delhi-110002. p 172-202.

Katsoulas, N.; D. Savas; I. Tsirogiannis; O. Merkouris; and C. Kittas (2009). Response of an eggplant crop grown under Mediterranean summer conditions to greenhouse fog cooling. Sci. Hortic., 123: 90-98.

Kittas, C.; T. Bartzanas and A. Jaffrin (2003). Temperature gradient in a partially shaded large greenhouse equipped with evaporative cooling pads. Biosystems Engineering, 85(1):87-94.

López, A.; D. L. Valera; F. D. Molina-Aiz; and A. Peña (2012). Sonic anemometry to evaluate airflow characteristics and temperature distribution in empty Mediterranean greenhouses equipped with pad-fan and fog systems. Biosyst., Eng. 113: 334-350.

Lychnos, G. (2010). Feasibility of a solar-powered liquid desiccant cooling system for greenhouses. Ph.D. Thesis, Aston University. 
Lychnos, G. and P. A. Davies (2008). A solar powered liquid-desiccant cooling system for greenhouses. ActaHortic., 2008.797.11: International Workshop on Greenhouse Environmental Control and Crop Production in Semi-Arid Regions.

Mishra, G. K., L. Yadav and M. Kumar (2016). A Review of desiccant based cooling systems using silica gel. Imperial J. of Interdisciplinary Res. (IJIR), 2 (12): 1224-1232.

Mehmet, A.D. and H.S. Hasan (2015). Performance analysis of a greenhouse fan-pad cooling system: gradients of horizontal temperature and relative humidity. Journal of Agricultural Sciences. 21: 132-143

Mohammad, A.T., S.B. Mat, M.Y. Sulaiman, K. Sopian, and A.A. AlAbidi (2013). Historical review of liquid desiccant evaporation cooling technology. Energy and Buildings, 67: December 2013: 22 33.

Montero, J.I. (2006). Evaporative cooling in greenhouses: Effect on microclimate, water use efficiency, and plant response. ActaHortic. 719: 373-384.

Montero, J.I., and I. Segal (1993). Evaporative cooling of greenhouses by fogging combined with natural ventilation and shading. Proc. of the Intern. Workshop on Cooling Systems for Greenhouses. Agritech, May 2-6.

Nguyen, T. N., L. H. Tang, Y. K. Peng, J. Y. Ni, and Y. N. Chang (2015). Effects of Composite Inorganic, Organic Fertilizer and Foliar Spray of Multi-nutrients on Growth, Yield and Quality of Cherry Tomato. J. Agr. Sci. Tech., 17: 1781-1788.

Pressman, E., M.M. Peet and D.M. Pharr (2002). The effect of heat stress on tomato pollen characteristics is associated with changes in carbohydrate concentration in the developing anthers. Annals of Botany. 90: 631-636.

Rafique, M.M., Sh. Rehman, A. Lashin and N. Al-Arifi (2016). Analysis of a solar cooling system for climatic conditions of five different cities of Saudi Arabia. Energies, 2016, pp, 13. 
Saeed, A., Kh. H., A. A. Khan and S. Iqbal (2007). Heat tolerance studies in tomato (Lycopersicon esculentum Mill.). Int. J. Agri. Biol., 9 (4): 649-652.

Sato, S., M.M. Peet and J.F. Thomas (2000). Physiological factors limit fruit set of tomato (Lycopersicon esculentum Mill.) under chronic, mild heat stress. Plant Cell Environ 23:719-726.

Sethi, V.P. and S.K. Sharma (2007). Survey of cooling technologies for worldwide agricultural greenhouse applications. Solar Energy. 81: 1447-1459.

Shamshiri, R., and W.I. Wan Ismail. (2014). Data acquisition for monitoring vapor pressure deficit in a tropical lowland shelter house. Plant Prod. Res. J. Appl. Sci., Engin. and Techn., 7(20): 111122.

Shamshiri, R., C.M. Hasfalina, A.J. Zakaria, P.Van. Beveren, D.B. Ahmad, W.I.W. Ismail (2016). Membership function model for defining optimality of vapor pressure deficit in closed-field cultivation of tomato. Acta Hort. (ISHS) 63: 1-7.

Singh, R.P., P.V. Vara Prasad, K. Sunita, S.N. Giri and K.R. Reddy (2007). Influence of high temperature and breeding for heat tolerance in cotton. Adv. Agron., 93: 313-85

Tahat, M. A. (2001). Heat-pump/energy-store using silica gel and water as working pair. Applied Energy, 69: 19-27.

Vollenweider, P. and M.S. Gunthardt-Goerg (2005). Diagnosis of abiotic and biotic stress factors using the visible symptoms in foliage. Environ. Pollut. 137:455-465.

Vox, G.M. Teitel, A. Pardossi, A. Minuto, F. Tinivella and E. Schettini (2010). Sustainable Greenhouse Systems. 2010. Nova Science Publishers, Inc., 79 pp.

Wikipedia, (2013). The free encyclopedia. http://en.wikipedia.org /wiki/Silica_gel.

Youssef, G.D.M. (2007). A thermal storage system for greenhouse energy conservation. Ph.D. Thesis, Fac. of Agric., Alexandria Univ.

Youssef, G.D.M. and Yakout, T.R. (2015). Effect of externally mounted shading screen on microclimatic conditions of greenhouse 
cantaloupe crop equipped with evaporative cooling system. J. Soil Sci. and Agric. Eng., Mansoura Univ., 6 (5): 667-685., 2015.

Youssef, G.D.M., T. R. Yakout, and Doaa, M. Mostafa (2015). Improving performance of the evaporative cooling system inside the greenhouses and its effect on tomato productivity. Alex. Sci. Exch. J. 36(1):80-94.

\section{الملخص العربي \\ تحسين مناخ الصوب الزراعية فى المناطق الحارة والرطبة بهرية باستخدام نظام تبريد تبخيري مطور جابر داهش محمد يوسف* و ناصر مصطفى العشماوي**}

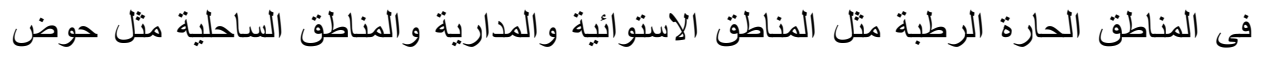

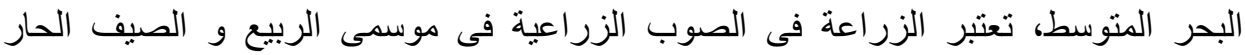

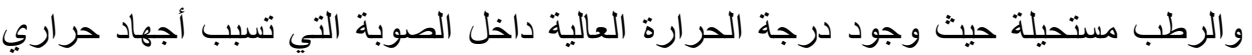
و عطش للنبات. يهذف هذه البحث إلى دراسة تأثير نظامي تبريد تبخيري مختلفين على المناخ داخل الصوبة الصنا

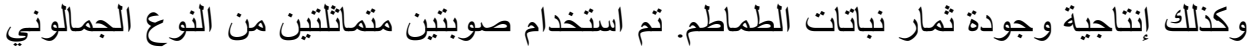

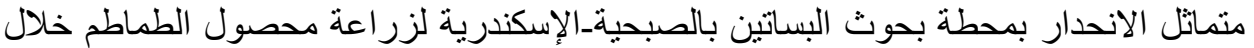

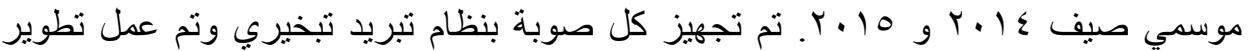
لإحداهما بإضافة مجفف (سيليكا جل) (نظام تبريد تبخيري مطور ) و الصوبة الأخرى تم تم استخدام

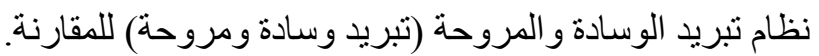

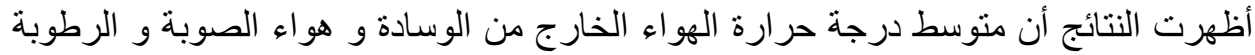

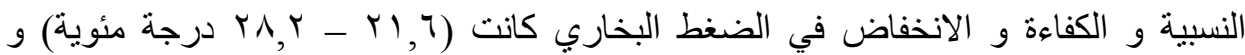

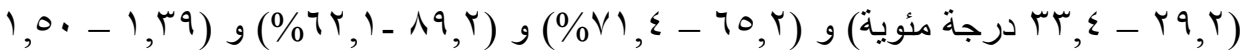

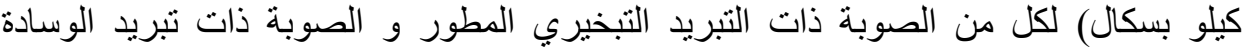

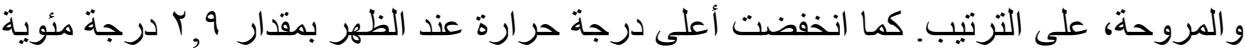
للصوبة ذات التبريد التبخيري المطور عن درجة حرارة الجو الخارجي، بينما كانت أعلى بمقدار كابر 1, درجة مئوية لصوبة التبريد الوسادة و المروحة. كانت نسبة الزيادة فى المحصول المبكر و عدد الثمار لكل نبات و وزن وزن الثمرة و المحصول الكيلى

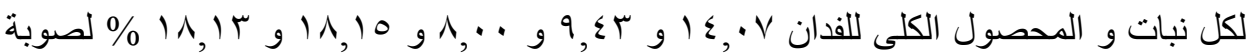

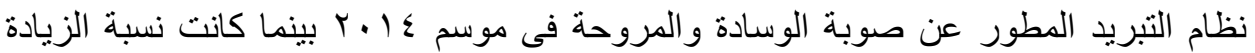
ا

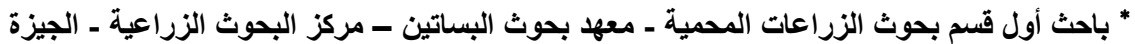

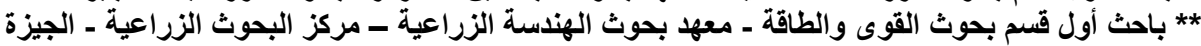

